\title{
New Type of Fluidizate-Explosive Rock in Sedimentary Strata (Torgashino Limestone Deposit, Eastern Sayan Mountains, Russia)
}

\author{
Svetlana S. Bondina ${ }^{1}$, Sergey A. Ananyev ${ }^{1}$, Tatiana A. Ananyeva ${ }^{1,2}$ \\ ${ }^{1}$ Siberian Federal University, Svobodny pr. 79, Krasnoyarsk, Russian Federation \\ ${ }^{2}$ Astafyev Krasnoyarsk Teachers' Training University, Lebedevoy St. 89, Krasnoyarsk, Russian Federation \\ Email: svetlana.bondina@gmail.com
}

How to cite this paper: Bondina, S.S., Ananyev, S.A. and Ananyeva, T.A. (2020) New Type of Fluidizate-Explosive Rock in Sedimentary Strata (Torgashino Limestone Deposit, Eastern Sayan Mountains, Russia). Open Journal of Geology, 10, 727-740. https://doi.org/10.4236/ojg.2020.107032

Received: April 27, 2020

Accepted: July 13, 2020

Published: July 16, 2020

Copyright $\odot 2020$ by author(s) and Scientific Research Publishing Inc. This work is licensed under the Creative Commons Attribution International License (CC BY 4.0).

http://creativecommons.org/licenses/by/4.0/

\begin{abstract}
The paper provides the results of comprehensive studies of bodies composed of different fluidolite types (psephitic, argillizite) and hydrothermalites found in the carbonate stratum of the Torgashino suite (Eastern Sayan Mountains, Russia). These rocks are the result of post-sedimentation processes imposed on limestones. Argillizites in the carbonate stratum are referred to a new type of fluidizate-explosive rock. Their low-temperature hydrothermal origin and association with the Later Ordovician tectono-magmatic activation of the area have been identified.
\end{abstract}

\section{Keywords}

Fluidolites, Hydrothermalites, Fluidizate-Explosive Process

\section{Introduction}

The term "fluidolites" was introduced into geology in the mid of the $20^{\text {th }}$ century in the paper of a known English petrologist Doris Reynolds "Fluidization as a geological process ..." [1]. In the end of the $20^{\text {th }}$ century, it was suggested allocating an additional subtype of magmatogenic fluidolites as part of magmatites in the modern rock classification (magmatites, sedimentites, and metamorphites). Many publications [2] are dedicated to them, too. According to the Petrographic code [3], fluidolites are considered to be a new type of endogenous rocks. The leading role in their formation belongs to fluids moving from various depths in the form of liquid-gas, solid-liquid-gas and solid-gas flows. While moving, the fluids fall in different baric conditions, which is due to decompression effects. This causes penetration (impregnation) of the fluid substance in the 
hosting rocks. Brecciated and frequently conglomerate-like rocks are formed as the result of these phenomena.

Fluidolites associated with sedimentary formations are rarer and studied more weakly. A. P. Kazak et al. in the monograph "Fluid-explosive formations in sedimentary strata" [4] provide a review and analysis of fluidolites formed at different time levels and in different geological conditions by the example of the Ladoga Area, the Southern Urals and the Arkhangelsk Region of Russia.

The study of the sedimentary carbonate strata composing the branches of the Eastern Sayan Mountains led to the discovery of two closely interconnected types of fluidolites in them. These are fragmentary fluidizate-explosive limestone formations-conglomerate-breccia with clay and sand cement and with aleuritic-psammite-psephite structure, and clayey fluidolites corresponding to ferruginized argillizites in terms of the composition [5].

The main purpose of the suggested studies is to analyze the processes imposed on the Torgashino carbonate stratum-fluidizate-explosive, and to study the products formed by them-fluidolites. The latter are represented by two types: large-size and coarse calcareous psephites and quartz-kaolinite argillizites. To reach this purpose, a set of tasks will be solved, including mineralogical, petrographic, geochemical, geochronological, thermobarometric studies with the involvement of the up-to-date methods described below.

\section{Research Methods}

The package of studies was based on the geological examination and sampling of limestones, vein fluidolites and hydrothermalites in $200 \mathrm{~m}$ sections of the stratum within the pits of the limestone and carbonate onyx deposit (being developed now). To identify the rock-forming and accessory minerals, thin sections were studied with the use of the polarizing microscope AxioImager A1 of Zeiss production; polished sections with the area of $30 \mathrm{~cm}^{2}$ to $500 \mathrm{~cm}^{2}$ were prepared for macroscopic and microscopic studies. The rocks were studied in the Laboratory of X-Ray Research Methods of the Common Use Center at the Siberian Federal University with the use of the following methods: X-ray spectral elementary analysis; X-ray phase analysis; and synchronous thermal analysis. Survey of X-ray patterns for phase analysis with the X-ray method was carried out using the automated X-ray diffractometric equipment of Shimadzu production-XRD-6000 and XRD-7000S (radiation of CuKa). The X-ray phase analysis was carried out with the use of the information-search system for $\mathrm{X}$-ray phase identification of materials combining qualitative and quantitative (with the "corundum figures" method) analyses. The X-ray pattern survey for elementary analysis with the X-ray spectral elementary analysis method was executed on an automated wave X-ray fluorescent spectrometer of Shimadzu production-XRF-1800 with Rh-anode. A non-standard method of fundamental parameters was used due to lack of standard specimens for the elementary analysis. The thermogravimetric/differential thermal analysis was carried out in the 
thermal analyzer SDT Q600 TA Instruments. To ensure reliability of the results of the X-ray phase analysis, the elementary composition of the specimens calculated on the basis of phase concentrations was compared with the data of the elementary analysis with the X-ray spectral elementary method and the synchronous thermal analysis data. Tests for 37 elements, including rare and rare-earth elements, were performed in the Common Use Center "Analytical Center for Geochemisty of Natural Systems" at the Tomsk State University with the ICP-MS method using the Agilent $7500 \mathrm{cx}$ device. To define the thermal formation conditions, cryometric and thermometric studies of two-phase inclusions of coarse-crystalline calcite were carried out on the basis of cleavable chips in the Institute of Geology and Mineralogy of the Siberian Branch of the Russian Academy of Sciences under the microscope OLYMPUSBX51 using the Linkam cryocamera. The detail study of the mineral composition of calcite onyx was carried out with the help of an electronic-probe analysis in the laboratory of the A.E. Fersman Mineralogical Museum. The specimens were examined in the scanning microscope CamScan-4D with the energy-dispersed spectrometer Link with the ISIS control system, with zooming from $18 \times$ to $4000 \times$. An argillizite sample was prepared, and geochronological tests of the absolute age with the $40 \mathrm{Ar} / 39 \mathrm{Ar}$ method were conducted on the basis of its micaceous fraction in the Laboratory of Isotope-Analytical Methods at the Institute of Geology and Mineralogy of the Siberian Branch of the Russian Academy of Sciences.

\section{Geological Structure}

The carbonate stratum, which is the object of our studies, is referred to the Torgashino suite (€1tr) and stretches to the south from Krasnoyarsk (Russia) (Figure 1).

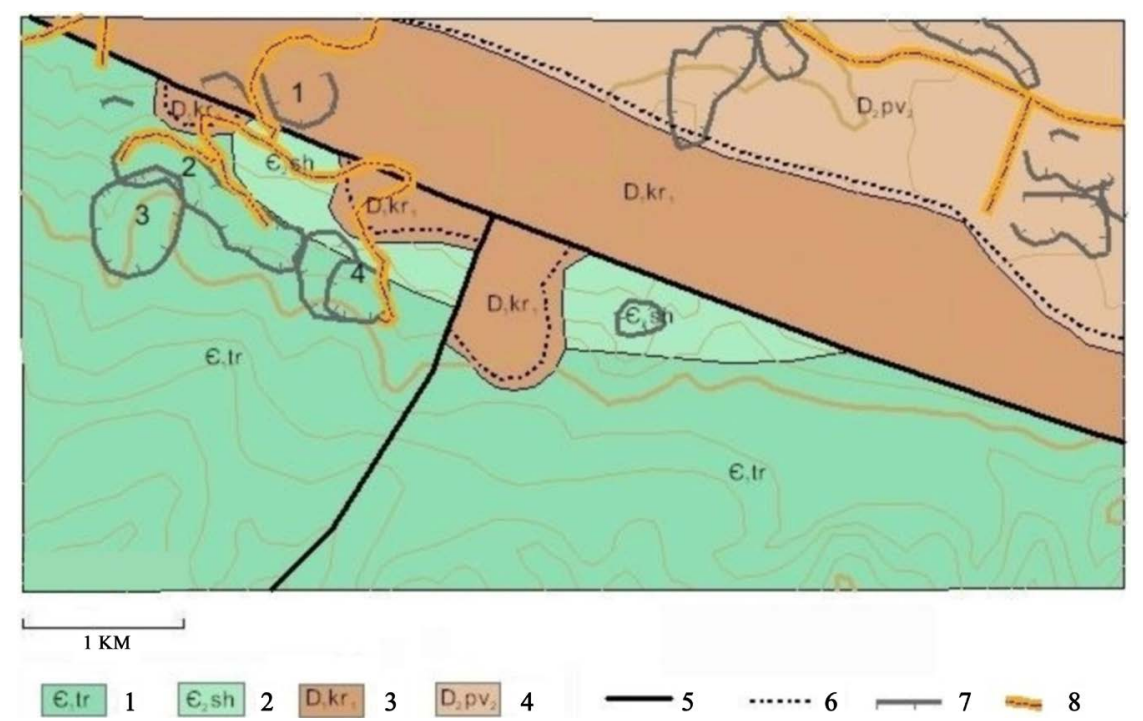

Figure 1. Geological map of the Torgashino area: 1-Torgashino Suite; 2-Shakhmatov Suite; 3-Karymov Suite (Lower Karymov Subsuite); 4-Pavlov Suite (Lower Pavlov Suite); 5-faults; 6-non-conformitied; 7-pit outlines; 8-roads. 
The suite was allocated by V. Zlatkovsky in 1885. The section of the Torgashino Ridge is a stratotype. Here, its deposits, forming high crags (Communist Mountain, Pioneer Mountain, etc.) frequently, occupy a significant area and compose both the axial part of the ridge and its slopes. They've been transformed to marbles at the contact with the rock of the Stolby intrusion. Most of the suite is composed of gray and light gray massive organogenic limestones. Stratified limestones are subordinated. There are dolomite interlayers in the top part of the section.

Carbonate strata are broken by faults of the northeastern orientation. Limestone is locally dolomitized and contains bodies of various hydrothermal and hydrothermal-metasomatic formations, locally dykes of altered basalts. At the northeastern piedmont of the Torgashino Ridge Lower Cambrian formations are overlapped with structural non-conformity by Lower Devonian clastic formations.

According to N. M. Zadorozhnaya [6], the limestones of the Torgashino suite form a complex organogenic structure, which can be considered as a reef complex consisting of smaller elementary organogenic structures (bioherms and biostromes) and associated breccia and stratified limestones. The total thickness of the suite reaches $900-1000 \mathrm{~m}$.

The magmatic formations within the studied area are represented by the rocks with variable petrographic composition, formed in the age interval from Later Riphean to Early Devonian. In total, five complexes have been identified: Akshep ( $\sigma \mathrm{RF} 3 ? \mathrm{a})$ composed mainly of serpentinite protrusions; Bakhtin subvolcanic $(\nu \mathrm{RF} 3 \mathrm{bh})$ represented by sills and dykes of green-stone altered small- and middle-grained microgabbro; Imir subvolcanic ( $\tau \beta \mathrm{O} 2-3 \mathrm{im}, \xi \pi \mathrm{O} 2-3 \mathrm{im}, \gamma \pi \mathrm{O} 2-3 \mathrm{im})$, which unites vent, dyke and sill formations of basalt-trachyandesite-trachyryolite composition; Stolby ( $\xi \mathrm{O} 3 \mathrm{st}$ ) in the form of stocks and laccoliths of syenite-granosyenite composition; and Chernosopkinsky (D1čr) including nekks and dykes of trachydolerites and dolerites [7].

The peculiar feature of the carbonate deposits is a wide distribution and wide variety of vein and fracture fluidolites-fragmentary and argillizite, as well as hydrothermalites-calcite onyxes and veins or large-crystal calcite in them.

\section{Discussion of Results of Studies and Conclusions}

\subsection{Fluidizate-Explosive Formations. Composition and Genesis features}

The fragmentary fluidolites are represented by breccia, conglomerate-breccia and pseudo-conglomerates with the shape of fracture or irregular bodies, with a cross-cutting nature and flat, diagonal or steep subvertical bedding (Figure 2). The clastic material of the conglomerate-breccia is represented by limestone corresponding to the hosting stratum in terms of the composition; the fragments content varies from $30 \%-40 \%$ to $70 \%-80 \%$ and above. Their size varies within a wide range: from several centimeters to large boulders. The cement in the 
rocks of this zone is commonly aleuritic-sandy; the spots where red-color clayey material-argillizite serves as a cementing mass are present.

Abrupt difference in fragment sizes, their comminuted nature and lack of sorting are commonly observed in the cementing matrix.

The study of thin sections of psammite-psephite fluidolites testifies to the fact that they correspond to hosting organogenic limestones in terms of the composition. As we have found out, they, similar to hosting limestones, contain calcified remains of rock-forming calcareous algae of the Epiphyton sp. genus and the Proaulopora glabra Krasn species. The thin sections also show that the limestones have been penetrated by very thin calcite veinlets prior to fluidizate-explosive events (Figure 3 ).

The typical features of the fluidolites are typical for fluidolites localized in the carbonate stratum [8]: crosscutting shape of bodies; incomplete roundness of large fragments; non-roundness of fragments of the psammitic and aleuritic sizes (meanwhile, the bigger the fragment, the more rounded it is); nature of roundness (it can be observed both on gibbous and on concave spots); shape of

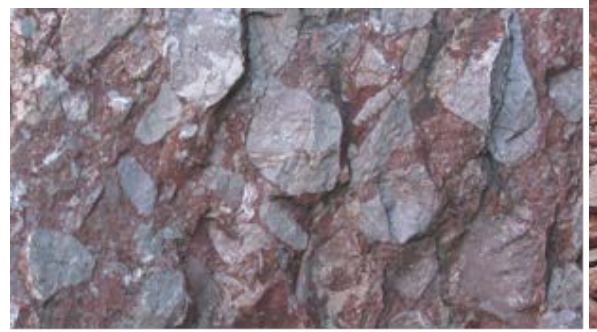

(a)

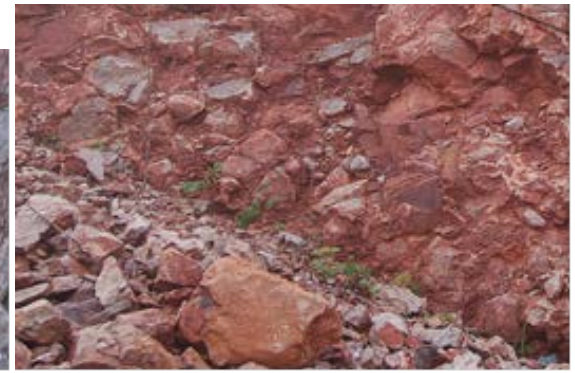

(b)

Figure 2. Fluidolites (pseudoconglomerate-breccia): (a) boulder fragments (field width 1 $\mathrm{m}$ ); (b) slope of the Cherny Mys pit, Level $+400 \mathrm{~m}$ (field width $1.5 \mathrm{~m}$ ).

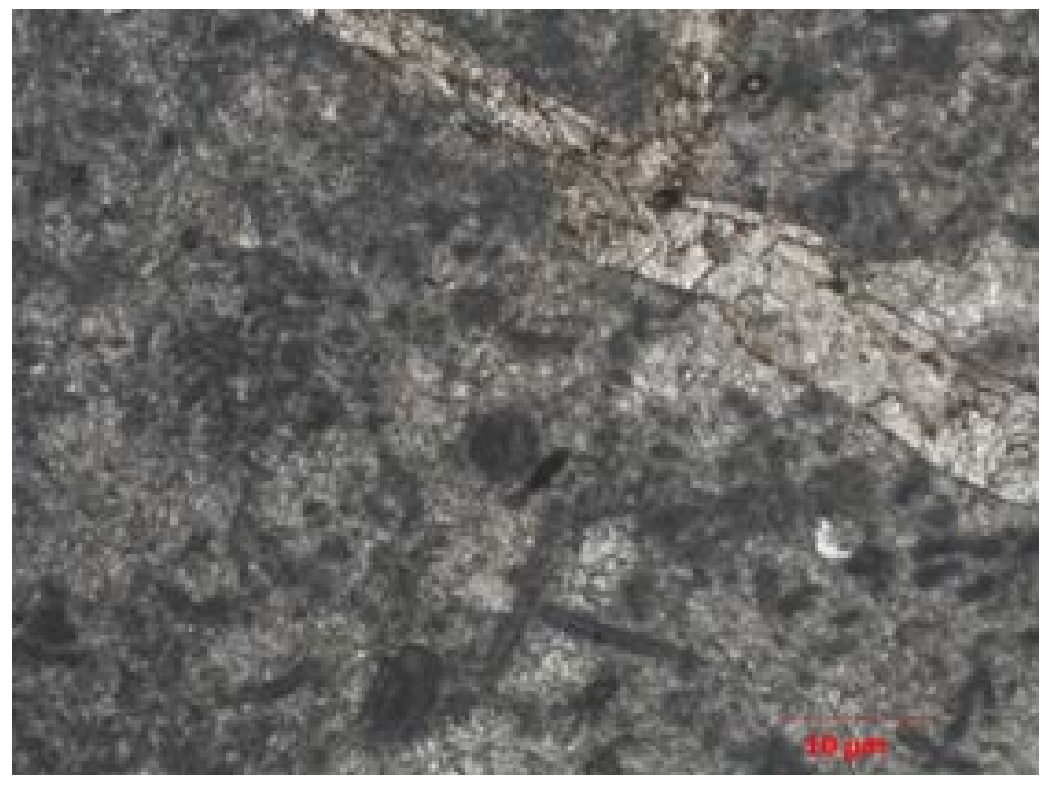

Figure 3. Organogenic limestone with calcareous algae and calcite veinlets. Parallel nicols. 
fragments (the fragments are represented by unflattened three-axis ellipsoids, which is common for typical boulders and pebble, but have the shape of a single-axis ellipsoid or even a ball); lack of sorting; abrupt increase in the size of fragments; comminuted exterior of small fragments (Figure 4); lack of sorting in the cementing matrix.

The rock of the matrix in this type of fluidolites has suffered imposed hematitization and partial crystallization. Hematite, the content of which in the samples varies from $0.49 \mathrm{wt} \%$ to $7.61 \mathrm{wt} \%$, is distributed irregularly, in spots, and sometimes rhythmically around larger limestone fragments.

Before our studies, the nature of occurrence of aleurite-psammite-psephite rocks in the limestone stratum in the form of fractured or irregular bodies with a crosscutting nature, with flat, diagonal or steep subvertical bedding, was explained differently. They were considered olistostromes, neptunian clastic dykes or, as Yu.A. Zadisensky et al. [9] think, a carst lithified by breccia.

We think that in this case we deal with fluidolites [10]. Fluidolites, or fluid-explosive formations, commonly occur as the result of interaction of deep fluids with the rocks that are permeable for them. The occurrence of fluid flows is associated with abrupt pressure drop-the effect of decompression in fracture structures and their further compression intrusion as the result of activation of tectonic movements. This causes a specific type of transfer-solid-gaseous, solid-liquid-gaseous or solid-liquid [4] [8].

In our case, the autochthonous part of the Torgashino suite suffered the impact of low-temperature hydrotherms with high pressure. The magma centers that appeared during the Middle Paleozoic tectonomagmatic activation of the area, which started in the Middle Ordovician age and was associated with the occurrence of basaltoid and trachybasaltoid volcanism of the Imir volcanic complex

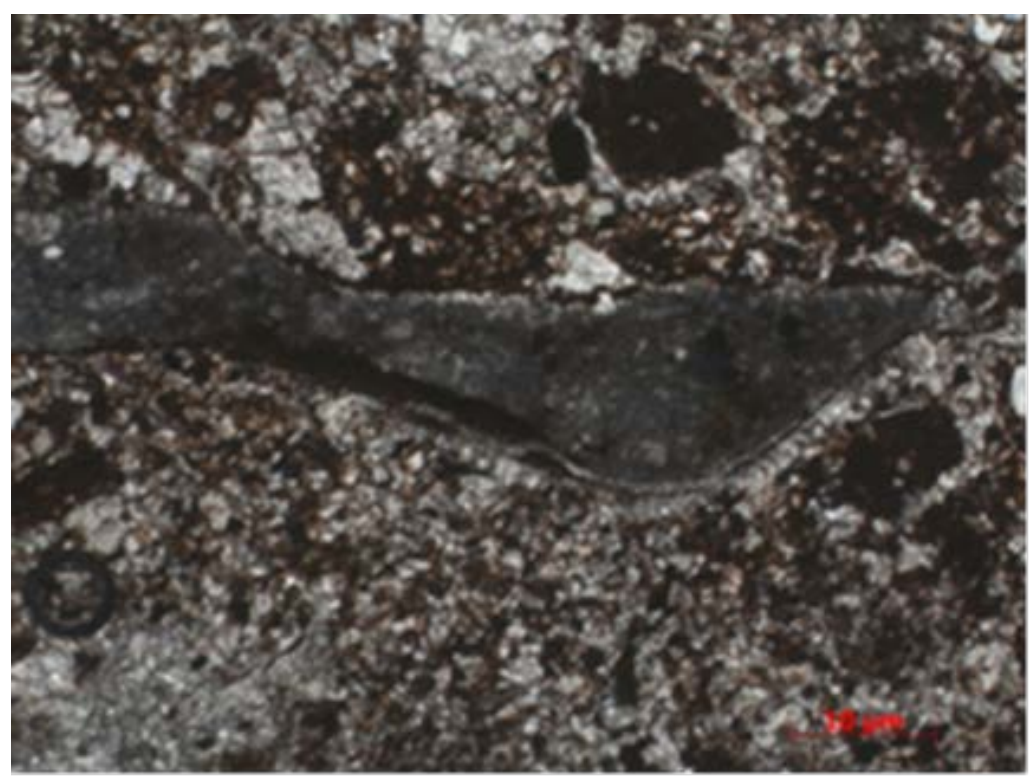

Figure 4. Comminuted fragment of limestone in hematite-altered calcite matrix. Thin section of fluidolite from boulder shown in Figure 2. Parallel nicols. 
(O2-3 im), observed within the Kachinsko-Shumikhinskaya depression in the northwestern contour of the Eastern Sayan Mountains folding system, served as their source. At the same stage of tectonic development, a syenite intrusion of the Stolby complex was formed (State ..., 2000). The Later Ordovician age of the Stolby complex is defined both on the basis of breaking-through of co-magmatic effusives of the Imir suite and on the basis of available radioisotopic datings for the Stolby massif-U-Pb $449 \pm 3$ and $451 \mathrm{Ma}, \mathrm{K}-\mathrm{Ar} 469 \mathrm{Ma}$ [11].

\subsection{Argillizites}

One of the features of limestones in the formation under study is their secondary pleochroism. They are reddish-brown, brown, with color variation from light to dark of various intensity. Our studies showed that limestone is colored by ferruginized argillizite filling all permeable ways from very thin fractures to vein bodies (Figure 5). Limestone as such is crypto- and small-grained gray, with various tints, from common light-gray to rarer dark-gray. The rock structure is massive, spotty, sometimes brecciated and quite rarely indistinctly stratified.

The study of argillizites with the use of the X-ray phase analysis and synchronous thermal analysis allows identifying the features of the mineral composition of this fluidolite type (Table 1).

The data of the X-ray spectral elementary analysis of argillizites shows the following composition in \% wt. (n/xmin-xmax/xav): O (18/52.30-58.76/56.01); $\mathrm{Si}$ (18/23.50-33.05/27.59); Al (18/5.63-11.47/8.83); Fe (18/0.83-4.85/2.59); C

(17/1.44-3.32/2.52); K (18/0.04-1.64/0.75); Ti (18/0.11-0.76/0.44); Ca

(18/0.03-1.64/0.45); $\mathrm{Mg}$ (18/0.01-0.56/0.21); $\mathrm{Na}$ (13/0.03-0.08/0.05); $\mathrm{Mn}$ (13/0.01-0.04/0.02); P (1/0.03); Sr (1/0.02).

The cluster analysis of the obtained data showed the levels of correlations between the chemical elements. With the significance level of R05 $=0.49$, valuable

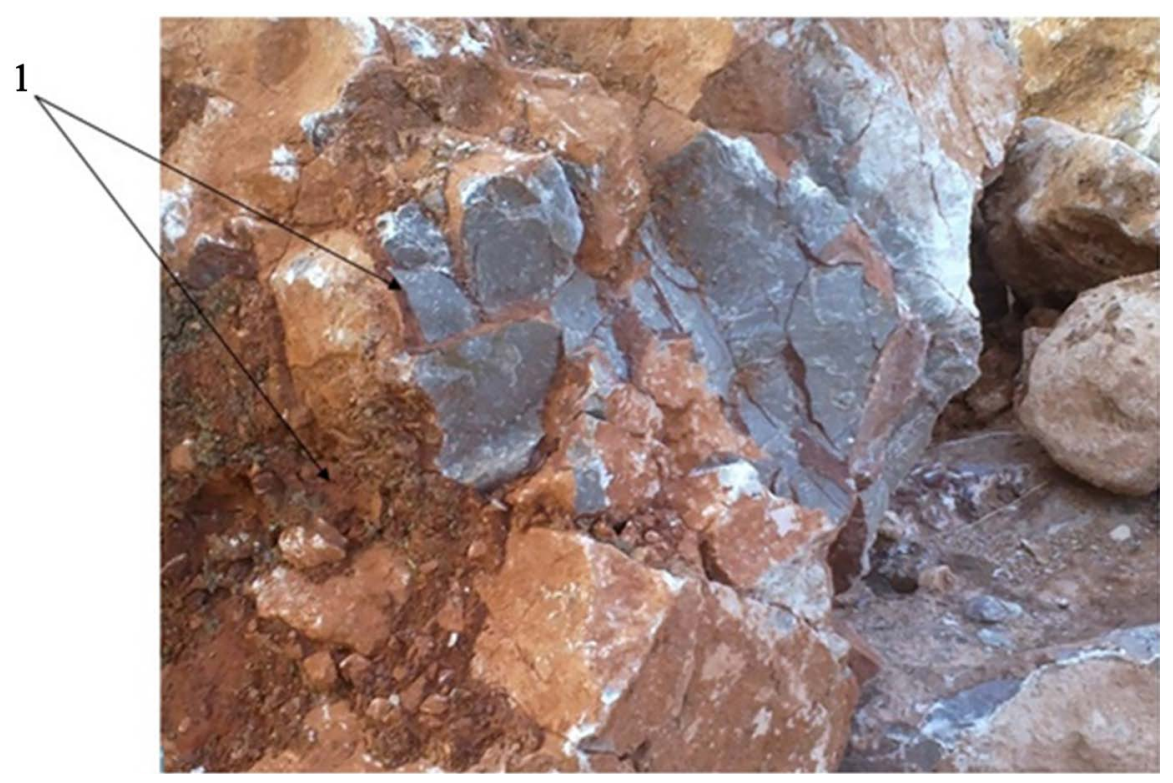

Figure 5. Fracture argillization (1) of limestones. 
Table 1. Mineral composition of argillizites on the basis of the results of the quantitative X-ray phase analysis (33 samples).

\begin{tabular}{|c|c|c|c|c|c|}
\hline Type of minerals & Item No. & Mineral & Formula & $\begin{array}{l}\text { Range of } \\
\text { grades, wt } \%\end{array}$ & $\begin{array}{l}\text { Presence } \\
\text { in samples }\end{array}$ \\
\hline \multirow{10}{*}{$\begin{array}{l}\text { Main rock forming } \\
\text { minerals }\end{array}$} & 1 & Quartz & $\mathrm{SiO}_{2}$ & $37.0-77.7$ & In all samples \\
\hline & 2 & Kaolinite & $\mathrm{Al}_{2} \mathrm{Si}_{2} \mathrm{O}_{5}(\mathrm{OH})_{4}$ & $9.90-47.2$ & In all samples \\
\hline & 3 & Muscovite & $\mathrm{KAl}_{2}\left[\mathrm{AlSi}_{3} \mathrm{O}_{10}\right](\mathrm{OH}, \mathrm{F})_{2}$ & $1.44-18.00$ & In 27 samples \\
\hline & 4 & Illite & $\begin{array}{l}\mathrm{K}<1 \mathrm{~A} 1<2\left[(\mathrm{Si}, \mathrm{Al})_{4} \mathrm{O}_{10}\right](\mathrm{OH})_{2} \times \mathrm{nH}_{2} \mathrm{O} \\
\text { (generalized formula of a group of minerals } \\
\text { referred to hydromica) }\end{array}$ & $1.14-9.22$ & In 22 samples \\
\hline & 5 & Hematite & $\mathrm{Fe}_{2} \mathrm{O}_{3}$ & $0.49-7.61$ & In 26 samples \\
\hline & 6 & Anatase & $\mathrm{TiO}_{2}$ & $0.34-1.40$ & In 27 samples \\
\hline & 7 & Nontronite & $\mathrm{Na} 0.3 \mathrm{Fe}^{23+}\left[(\mathrm{Si}, \mathrm{Al})_{4} \mathrm{O}_{10}\right] \times(\mathrm{OH})_{2} \cdot \mathrm{nH}_{2} \mathrm{O}$ & $6.5-30.0$ & In Samples 22, 23, 24 \\
\hline & 8 & Tosudite & $\mathrm{Na} 0.5(\mathrm{Al}, \mathrm{Mg}) 6 \times\left[(\mathrm{Si}, \mathrm{Al})_{8} \mathrm{O}_{18}\right](\mathrm{OH})_{12} \cdot 5 \mathrm{H}_{2} \mathrm{O}$ & $11.62-17.8$ & In Samples 22, 23, 24 \\
\hline & 9 & Clinochlore & $\left(\mathrm{Mg}, \mathrm{Fe}^{2+}\right) 5 \mathrm{Al}\left[\mathrm{AlSi}_{3} \mathrm{O}_{10}\right] \times(\mathrm{OH})_{8}$ & $2.45-3.47$ & In Samples 22, 23, 24 \\
\hline & 10 & Calcite & $\mathrm{Ca}(\mathrm{CO})_{3}$ & $0.18-3.20$ & In 12 samples \\
\hline \multirow{18}{*}{$\begin{array}{l}\text { Secondary minerals } \\
\text { and minerals, } \\
\text { which are rare in } \\
\text { this type of rock }\end{array}$} & 11 & Siderite & $\mathrm{Fe}^{2+}(\mathrm{CO})_{3}$ & $0.34-2.46$ & In 14 samples \\
\hline & 12 & magnetite & $\mathrm{Fe}^{2+} \mathrm{Fe}^{23+} \mathrm{O}_{4}$ & $0.28-2.44$ & In Samples 22, 7, 12, 22 \\
\hline & 13 & Rutile & $\mathrm{TiO}_{2}$ & $1.23-2.32$ & In Samples 3, 4, 10, 17 \\
\hline & 14 & Lizardite & $\mathrm{Mg}_{3} \mathrm{Si}_{2} \mathrm{O}_{5}(\mathrm{OH})_{4}$ & $1.20-3.26$ & In Samples 10,17, 21, 22 \\
\hline & 15 & Ankerite & $\mathrm{Ca}\left(\mathrm{Fe}^{2+}, \mathrm{Mg}, \mathrm{Mn}\right)\left(\mathrm{CO}_{3}\right)_{2}$ & $0.60-1.08$ & In Samples 21, 26 \\
\hline & 16 & Gibbsite & $\gamma-\mathrm{Al}(\mathrm{OH})_{3}$ & $0.67-4.88$ & In Samples 28, 29 \\
\hline & 17 & Talc & $\mathrm{Mg}_{3}\left[\mathrm{Si}_{4} \mathrm{O}_{10}\right](\mathrm{OH})_{2}$ & 8.82 & Sample 5 \\
\hline & 18 & Montmorillonite & $(\mathrm{Na}, \mathrm{Ca}) 0.3\left[(\mathrm{Al}, \mathrm{Mg})_{2} \mathrm{Si}_{4} \mathrm{O}_{10}\right] \times(\mathrm{OH})_{2} \cdot \mathrm{nH}_{2} \mathrm{O}$ & 7.05 & Sample 5 \\
\hline & 19 & Fayalite & $\mathrm{Fe}_{2} \mathrm{SiO}_{4}$ & 4.58 & Sample 29 \\
\hline & 20 & Orthoclase & $\mathrm{K}[\mathrm{AlSi3O} \mathrm{O}]$ & 2.89 & Sample 21 \\
\hline & 21 & $\begin{array}{l}\text { Berthierine } \\
\text { (kaolinite-serpe } \\
\text { ntinite group) }\end{array}$ & $\left(\mathrm{Fe}^{2+}, \mathrm{Fe}^{3+}, \mathrm{Al}\right)_{3} \times\left[(\mathrm{Si}, \mathrm{Al})_{2} \mathrm{O}_{5}\right](\mathrm{OH})_{4}$ & 3.47 & Sample 23 \\
\hline & 22 & Bernalite & $\mathrm{Fe}(\mathrm{OH})_{3}$ & 2.60 & Sample 31 \\
\hline & 23 & Andradite & $\mathrm{Ca}_{3} \mathrm{Fe}_{2}\left[\mathrm{SiO}_{4}\right]_{3}$ & 1.97 & Sample 2 \\
\hline & 24 & Augite & $\mathrm{Ca}(\mathrm{Mg}, \mathrm{Fe}, \mathrm{Al})\left[(\mathrm{Si}, \mathrm{Al})_{2} \mathrm{O}_{6}\right]$ & 1.52 & Sample 20 \\
\hline & 25 & Aragonite & $\mathrm{Ca}(\mathrm{CO})_{3}$ & 1.49 & Sample 2 \\
\hline & 26 & Goyazite & $\mathrm{SrAl}_{3}\left(\mathrm{PO}_{4}\right)\left(\mathrm{PO}_{3} \mathrm{OH}\right)(\mathrm{OH})_{6}$ & 1.19 & Sample 31 \\
\hline & 27 & Diopside & $\mathrm{CaMg}\left[\mathrm{Si}_{2} \mathrm{O}_{6}\right]$ & 1.00 & Sample 26 \\
\hline & 28 & $\begin{array}{l}\text { Magnesio-cafrol } \\
\text { ite }\end{array}$ & $\mathrm{MgAl}_{2}\left[\mathrm{Si}_{2} \mathrm{O}_{6}\right](\mathrm{OH})_{4}$ & 0.56 & Sample 26 \\
\hline
\end{tabular}

Note $-*$ - mineral remains after acidic dissolution.

negative correlations were established between oxygen and $\mathrm{Fe}, \mathrm{Ca}, \mathrm{Mn}$, as well as silicon and $\mathrm{Al}, \mathrm{Fe}, \mathrm{Ti}, \mathrm{Ca}$. Positive valuable correlations were established between iron and $\mathrm{Ca}, \mathrm{Mn}$, and a very strong one between $\mathrm{K}$ and $\mathrm{Mg}$. 
Three positively connected groups of elements were identified: $\mathrm{P}-\mathrm{Sr}-\mathrm{O}-\mathrm{Si}$; $\mathrm{K}-\mathrm{Mg}-\mathrm{C}-\mathrm{Na}$; Fe-Mn-Ca-Ti-Al. They have negative relations with each other, and among them the relation of the latter group of elements with the first two ones is valuable (Figure 6). With exclusion of the impurity elements from consideration, the presence of valuable negative correlations between the mineral forming elements $\mathrm{Fe}-\mathrm{Ti}$ and $\mathrm{O}-\mathrm{Si}$ and between $\mathrm{Si}$ and $\mathrm{Al}$ can be stated.

Calcite crystals extracted from argillizites and veins of coarse-crystalline calcite mostly contain single-phase liquid inclusions, which testify to the hydrothermal nature of the mineral formation process. In some areas small double-phase inclusions can be found, containing a gas bubble and a phase of liquid water solution. The temperature of homogenization of double-phase inclusions (Figure 7) is $110^{\circ} \mathrm{C}$ to $150^{\circ} \mathrm{C}$, which testifies to the low-temperature conditions

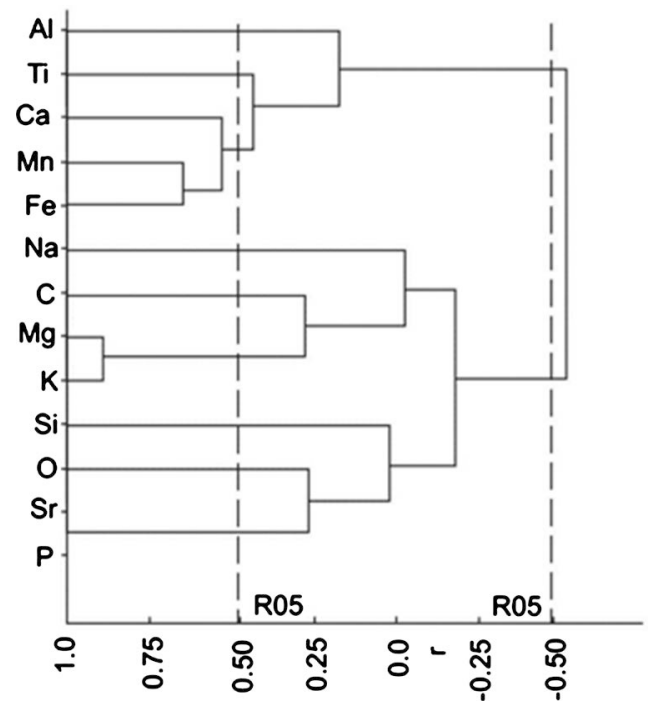

Figure 6. Cluster analysis of elementary composition of argillizites.

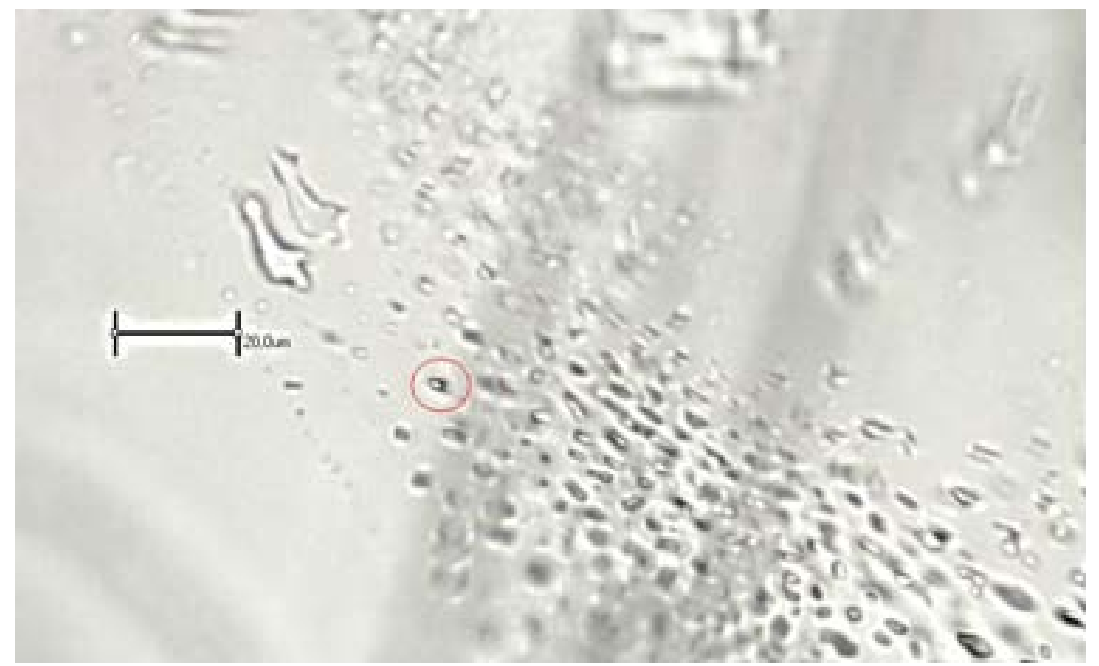

Figure 7. Two types of inclusions in calcite: single-phase-liquid, generally present in the photo, with a dominating position; and double-phase-gas-liquid inclusion marked in red. 
of formation of the rocks under study.

\subsection{Hydrothermalites-Calcite Onyxes and Veins of Large-Crystal Calcite}

Carbonate metasomatosis occurring in the argillizite matrix filling cavities in limestone led to the formation of calcite onyxes. Rocks reflecting the initial stage of occurrence of carbonate onyx in argillizite vein bodies were found (Figure 8).

The study of thin sections of calcite onyxes collected from different veins shows a single mechanism of formation of banded aggregates. The growth of calcite aggregates in the argillizite mass starts from some surface (fracture wall, argillizite interlayer) with the formation of a zone of subparallel thin-columnar grains, and is completed as the result of geometric selection with the occurrence of larger cross-columnar crystals. Their growth is completed with the formation of idiomorphic heads which deform the argillizite substratum (Figure 9). When a part of the argillizite substratum is preserved in the form of an interlayer, the growth of the calcite aggregate reoccurs. As the result, we observe a rhythmic

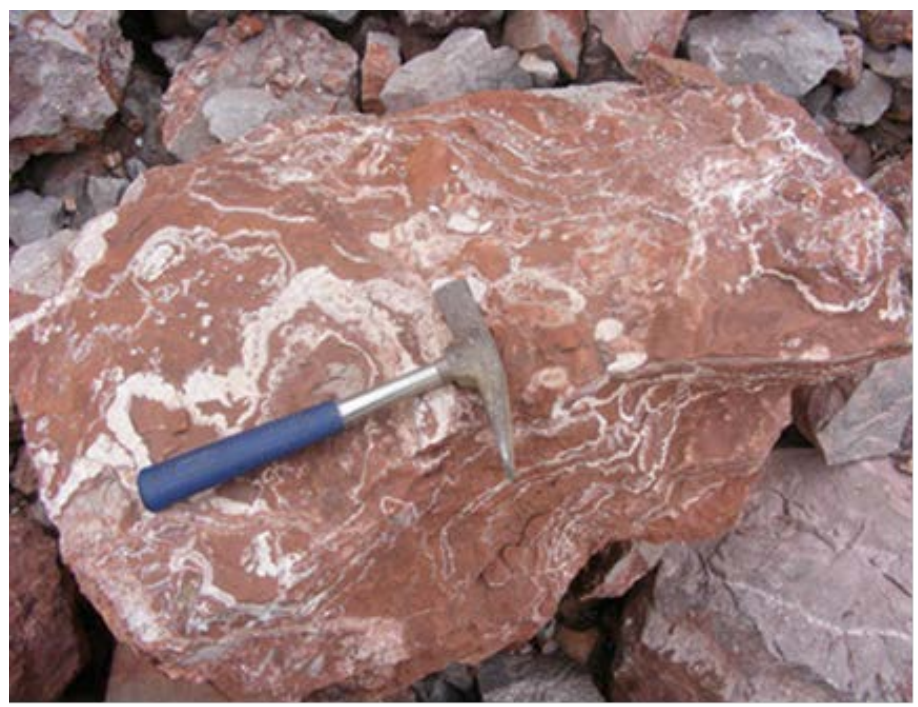

Figure 8. Argillizite with calcite onyx being formed.
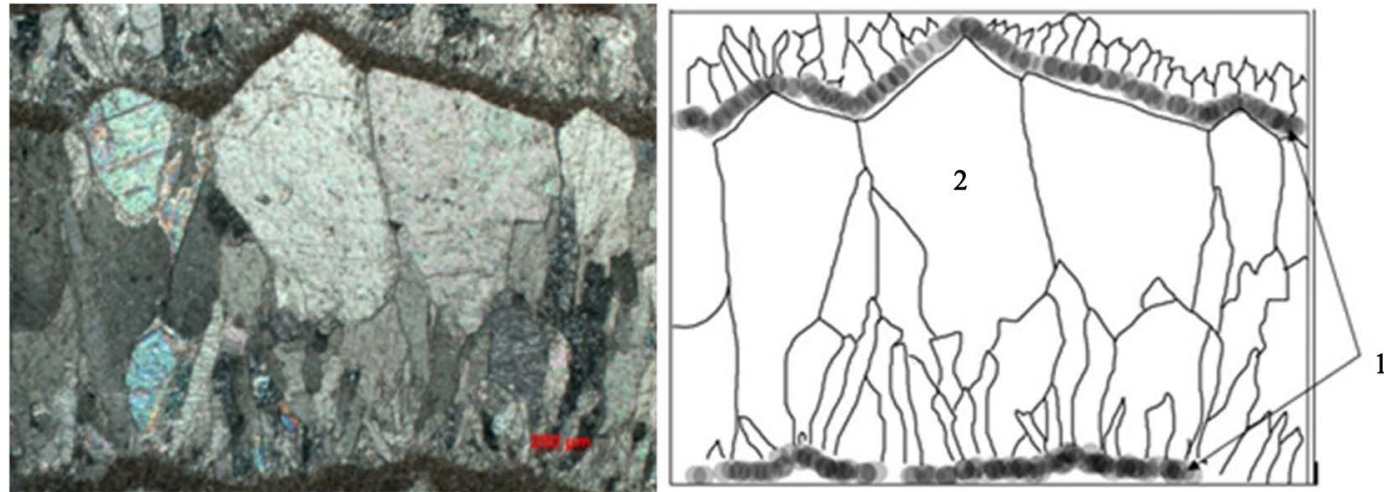

Figure 9. Thin section of calcite onyx (crossed nicols) and its schematic drawing. (1 argillizite, 2 calcite crystals). 
aggregate with a distinct vector of its development.

In some cases brecciated onyx is found among the considered type of hydrothermalites. Clearly expressed disjunctive dislocations are its peculiar feature. Multiple fractures and crushed zones were cemented with later yellowish-white large-crystalline calcite or argillizite-altered calcite during further vein expansion (Figure 10). The color of onyx in such veins is commonly dark-brown or reddish-brown, which is associated with the presence of ferruginized argillizite. Therefore, brown bands have thin-banded, cryprocrystalline and even pelitomorphic structure, and the light (pink-white and white) ones have middle-banded structure.

The above-described studies show that clayey products in limestones are typical ferriferous argillizites of quartz-kaolinitic paragenesis. However, the mechanism of argillization is uncommon. Traditionally, argillization occurs by means of metasomatic rock replacement. In our case, limestones are not replaced but impregnated by clayey products.

Algillization of limestones is associated with the stage of tectonomagmatic activation of this region and with the occurrence of basaltoid and trachybasaltoid volcanism of the Imir volcanic complex (O2-3 im), which occurred within the Kachinsko-Shumikhinskaya depression in the northwestern contour of the Eastern Sayan Mountains folding system. Tectonic deformation and crushing of the carbonate stratum was accompanied by intrusion of pressurized low-temperature hydrotherms containing argillizite mass.

This process was of fluidizate-explosive nature and led to the occurrence of fluidolites [10]. In terms of the formation mechanism, argillizites can be considered as a specific type of fluidolites, which are formed as independent bodies and serve as cement of psammite-psephite calcareous fluidolites. In thin sections of the latter the clastic structure is typical not for carbonates only, but for quartz grains as well (Figure 11).

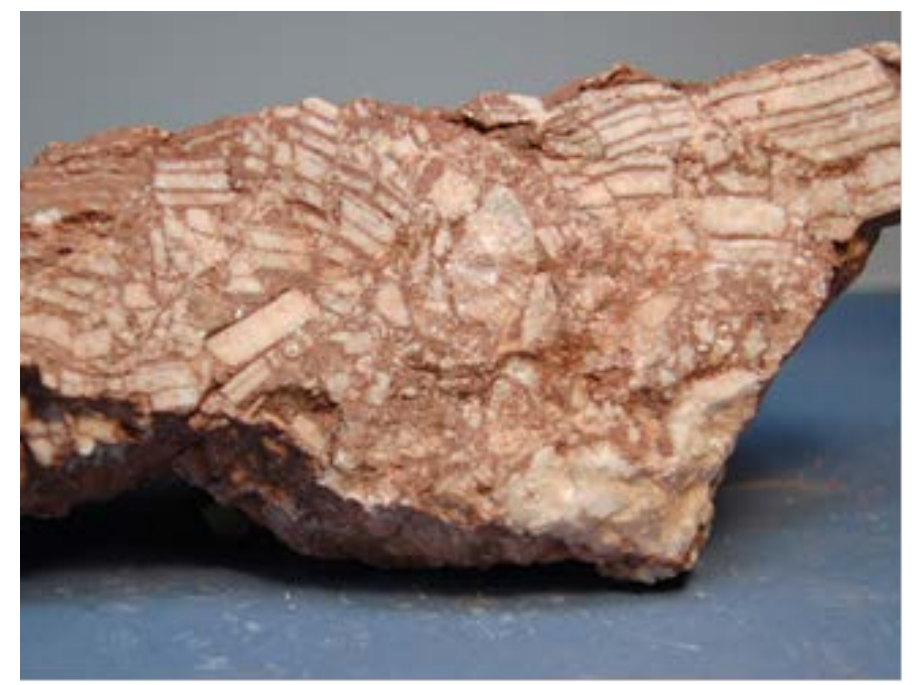

Figure 10. Brecciated calcite onyx. It consists of fragments of coarse-banded onyx cemented by argillized calcite. 


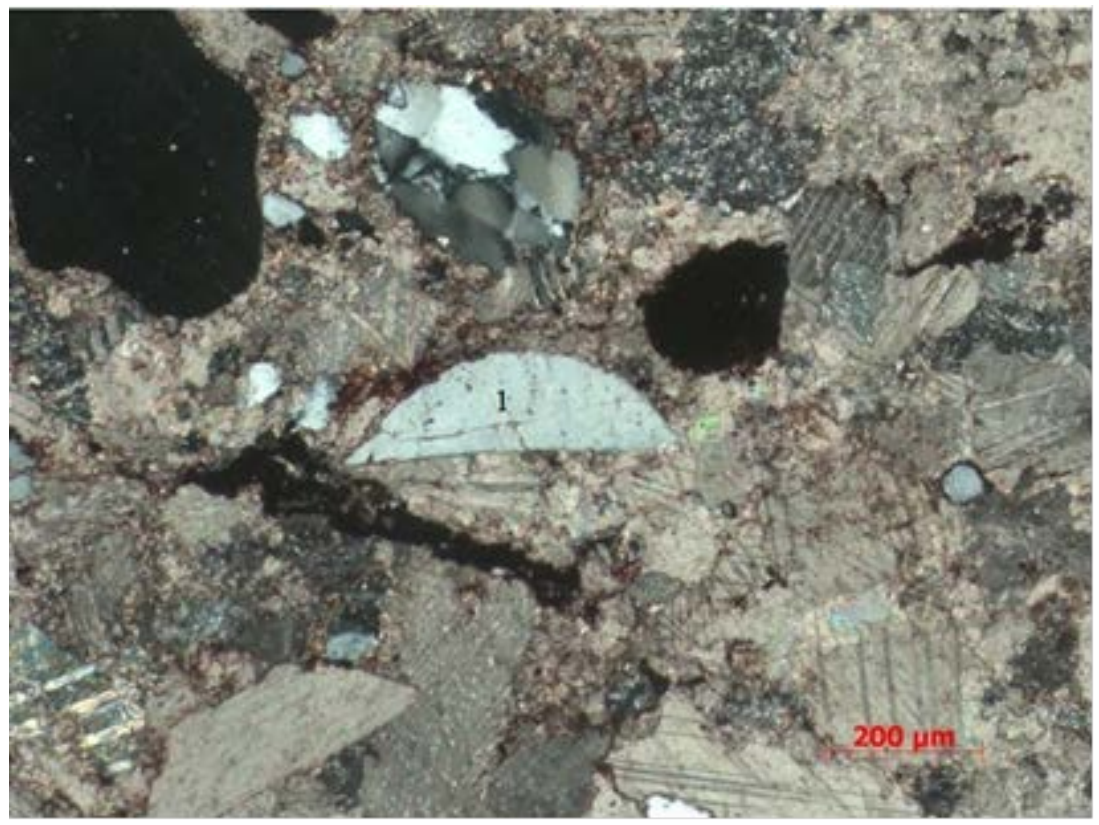

Figure 11. Thin section of argillizite-altered fluidolite cement. In the center there is a rounded comminuted quartz fragment (1). Crossed nicols.

Geochronological tests of the absolute age with the 40Ar/39Ar method were conducted for solution of the problem of the fluidizate process age on the basis of the micaceous fraction of argillizites in the laboratory of isotope-analytical methods of the Institute of Geology and Mineralogy of the Siberian Branch of the Russian Academy of Sciences. The isotopic dating of argillizite fluidolites showed the correspondence of the time of their formation to the age of the Stolby syenite-granosyenite complex $\xi \mathrm{O} 3 \mathrm{st}-458.1 \pm 5.8 \mathrm{Ma}$.

Based on the performed studies fluidizate-explosive formations were identified for the first time within sedimentary carbonate strata. As was already mentioned above, tectonic activation of the Upper Ordovician age served as a release mechanism for the formation of fluidolites and associated hydrothermalites (calcite onyxes) in the stratum of the Torgashino formation. Intrusion of pressurized low-temperature hydrotherms with a high content of the argillizite mass occurred repeatedly after the phase of decompression of multiple fracture structures and crushed zones. This process was of fluidizate-explosive nature, reminding of mud volcanism in terms of the mechanism [12]. Its development led to the formation of various types of fluidolites. At the early stages coarse psephitic fluidolites were formed in the conditions of high pressure gradients and water and mud solution motion speeds (Figure 12).

Finer-fragmented carbonate material with hematitized cement and red clayey products calcitated to a different extent serve as a cementing matrix in them. The latter, as we found out, are hematitized quartz-kaolinite argillizites. Since argillizites do not have a metasomatic nature imposed on limestone but are impregnated products closely associated with clastic fluidolites, we referred them to the second type of fluidolites. Their formation took a long time-from early 


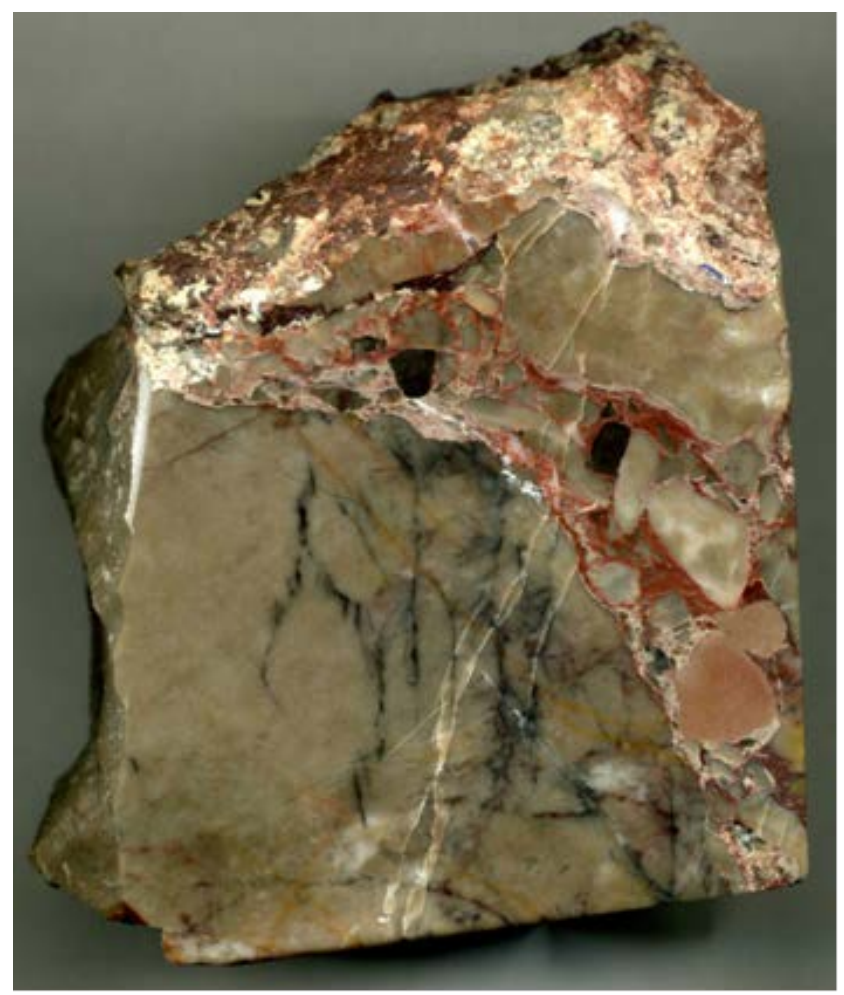

Figure 12. Psephitic fluidolite $(9 \times 8 \mathrm{~cm})$.

pressurized and mobile mud flows to slowly moving viscous plastic masses containing carbonate fragments of various nature (sedimentary, hydrothermal). This is associated with compression pressure gradients in fracture structures, falling in time, and the duration of tectonic deformation processes.

The low temperature hydrothermal process which accompanied and completed the fluidizate-explosive process led to the occurrence of the third type of formations-hydrothermalites-calcite onyxes and coarse-crystalline calcite veins.

\section{Conflicts of Interest}

The authors declare no conflicts of interest regarding the publication of this paper.

\section{References}

[1] Reynolds, D.L. (1954) Fluidization as a Geological Process and Its Bearing on the Problem of Intrusive Granites. American Journal of Science, 252, 577-614.

https://doi.org/10.2475/ajs.252.10.577

[2] Makhlayev, L.V. and Golubeva, I.I. (1999) Fluidizates and Their Position in Rock Systematics. Proceedings of the 13th Geological Conference of the Republic of Komi, Syktyvkar, Vol. 2, 165-167.

[3] (2009) Petrographic Code of Russia. Third Edition, VSEGEI Publishing House, St. Petersburg, $160 \mathrm{p}$.

[4] Kazak, A.P., Kopylova, N.N., Tolmacheva, E.V. and Yakobson, K.E. (2008) Flu- 
id-Explosive Formations in Sedimentary Complexes. GGUP "Mineral”, 42 p.

[5] Bondina, S.S., Ananyev, S.A. and Ananyeva, T.A. (2015) Age of Hydrothermalites of Fluidizate-Explosive Process in Carbonate Stratum of the Torgashino Formation (East Sayan Mountains). News of the Siberian Division of the Section of Earth Sciences of the Russian Academy of Natural Sciences, No. 2, 57-62.

[6] Zadorozhnaya, N.M. (1974) Early Cambrian Organogenic Structures in the Eastern Part of the Altay-Sayan Folding Area. Environment and Life in the Geological Past (Paleoecological Problems). Nauka, Novosibirsk, 159-186.

[7] Sazonov, A.M., Tsykin, R.A., Ananyev, S.A., Yu, O., Perfilova, M.L. and Makhlayev, O.V. (2010) Sosnovskaya Guide on Geological Traverses in the Area of Krasnoyarsk. Siberian Federal University, Krasnoyarsk, 212 p.

[8] Golubeva, I.I. (2003) Magmatogenic Fluidizate-Explosive Formations of the North of Urals. Urals Branch of the Russian Academy of Sciences, Yekaterinburg, $139 \mathrm{p}$.

[9] Zadisensky, Yu.A., Mironyuk, G.V., et al. (2008) Report on the Subject: "Revision and Evaluation Works for Allocation of Subsurface Areas Containing Collection Geological Materials (Krasnoyarsk Territory). Museum of Geology of Central Siberia, Krasnoyarsk, $221 \mathrm{p}$.

[10] Tsykin, R.A., Bondina, S.S. and Ananyev, S.A. (2012) Fluidolites and Other Hydrothermalites of the Torgashino Carbonate Lower Cambrian Formation (Eastern Sayan Mountains). Bulletin of the Astafyev Krasnoyarsk State Teachers' Training University, No. 3, 332-339.

[11] Rublyev, A.G. and Yu, P. (1996) Ordovician Magmatism of East Sayan Mountains, Minusa and Kuznetsk Alatau. Geology and Mineral Resources of the Krasnoyarsk Territory and the Republic of Khakasia, Krasnoyarsk, No 3, 58-63.

[12] Bondina, S.S., Ananyev, S.A., Ananyeva, T.A. and Tsykin, R.A. (2013) Argillisites of the Torgashino Limestone Deposit. Bulletin of the Astafyev Krasnoyarsk State Teachers' Training University, No. 3, 250-255. 